\title{
Assessment of exposure to 2,4-dichlorophenoxyacetic acid in the chemical industry: results of a five year biological monitoring study
}

\section{Knopp}

Abstract

Data on individual exposure to 2,4-dichlorophenoxyacetic acid (2,4-D) in herbicide production plants are limited. Hence, the urinary excretion of this herbicide was measured during a five year (1985-1989) biological monitoring study of 27 men and 18 women employees exposed during the production and formulation of 2,4-D and related sodium and dimethylamine salts. In separate studies, specimens of urine were collected in the morning, or during the last three hours of a working shift, or over a 24 hour period (1200 to 1200 or 0800 to 0800 ) and were analysed by an immunochemical method (2,4-D radioimmunoassay (RIA)). Urinary 2,4-D concentrations varied within a large scale from only a few $\mu \mathrm{g} / \mathrm{l}$ to several $10 \mathrm{~s}$ of $\mathrm{mg} / \mathrm{l}$. During a week, herbicide excretion increased, culminating on Friday. At the weekend, when no work was done, 2,4-D elimination decreased but did not return to zero in any case. After an interruption of exposure for about three weeks, urinary 2,4-D was no longer detectable. About five days after restarting work, body concentrations had built up again. Measurements of 2,4-D concentrations in air at different workplaces showed that herbicide concentrations did not exceed $0.5 \mathrm{mg} / \mathrm{m}^{3}$. As well as inhalation, dermal 2,4-D absorption seemed to play an important part in total uptake of herbicide. Furthermore, a strong correlation was found $(r=0.9628)$ between 2,4-D urinary concentration, adjusted for endogeneous creatinine, and the estimated amount of absorbed herbicide. Estimated absorbed doses.were, in most cases, well below $0.1 \mathrm{mg}$ 2,4-D/kg body wt/day. Sometimes this concentration was greatly exceeded. Thyroid hormone concentrations in blood were measured as well. No notable abnormalities were found. Exposed subjects were also typed for histocompatibility locus antigens (ABC antigens). The immunochemical determination of 2,4-D in specimens of urine proved to be a simple, cost effective, and non-invasive method to measure human exposure.

\section{(Occup Environ Med 1994;51:152-159)}

The suspected carcinogenic potential of 2,4-dichlorophenoxyacetic acid (2,4-D) has raised concern about the exposure of workers to it. By contrast with many applicator studies in agriculture and forestry, data on the occupational exposure to $2,4-\mathrm{D}$ in herbicide production plants are limited..$^{1-9}$ Generally, in these studies only ambient air concentration of 2,4-D at the workplace was measured. As the herbicide is absorbed readily through the skin, these measurements do not necessarily show the total amount absorbed into the body. By obtaining actual individual exposure data a better assessment of the potential health hazard to employees in chemical plants is possible.

In the past, a radioimmunochemical assay for 2,4-D developed at our laboratory was successfully applied to the biological monitoring of herbicide sprayers. ${ }^{10}$ The object of the present study was to measure 2,4-D urinary excretion of employees engaged in the production, formulation, and packaging of 2,4-D and related salts in order to estimate average rates of absorption. Investigations were extended over several years.

\section{Materials and methods}

SUBJECTS AND PRODUCTION

The study group comprised the staff of a herbicide (2,4-D sodium and dimethylamine salts) production plant, consisting overall of 27 men (mean age, 42 (range 26-58) years) and 18 women (mean age, 39 (range 17-61) years). Eight studies were performed between 1985 and 1989 with varying numbers of the workers included. Each worker was coded with a number that was strictly maintained throughout.

The process used in the manufacture of 2,4-D was based on the condensation reaction between 2,4-dichlorophenol and monochloroacetic acid under alkaline conditions (the Pokorny process). The raw materials of the chlorination process were molten phenol and chlorine gas. Water soluble 2,4-D amine salt was formed with dimethylamine. The process started with the neutralisation of acidic raw materials by sodium hydroxide in a neutralisation vessel. Raw materials were then transferred to a reaction vessel where the condensation reaction took place (condensation station). The resultant water soluble salt of the phenoxy acid was filtered, dried, and removed to be packed. For the production of the amine, the sodium salt was converted to the free acid by adding hydrochloric acid in an acidification vessel and the resulting 2,4-D acid was filtered, dried again (2,4-D acid filter station), and finally aminated in a 
Table 1 Specification of the different studies

\begin{tabular}{|c|c|c|c|c|}
\hline $\begin{array}{l}\text { Study } \\
\text { No }\end{array}$ & Year & $\begin{array}{l}\text { Size of the } \\
\text { study group }\end{array}$ & Study design & Period of urine and blood specimen collection \\
\hline 1 & 1985 & $\begin{array}{l}14 \text { men } \\
10 \text { women }\end{array}$ & Spot sample (urine and blood) & $\begin{array}{l}\text { Within the first two hours of working shift } \\
\text { (Friday) }\end{array}$ \\
\hline 2 & 1986 & $\begin{array}{l}10 \text { men } \\
\text { seven women }\end{array}$ & Spot sample (urine and blood) & $\begin{array}{l}\text { Within the first two hours of a working shift } \\
\text { (Friday) }\end{array}$ \\
\hline 3 & 1986 & $\begin{array}{l}\text { seven men } \\
\text { two women }\end{array}$ & $\begin{array}{l}\text { Spot samples (shift urine) } \\
\text { over a weekly interval }\end{array}$ & $\begin{array}{l}\text { Within the last three hours of a working shift } \\
\text { during the whole working week and at the } \\
\text { weekend }\end{array}$ \\
\hline 4 & 1986 & $\begin{array}{l}12 \text { men } \\
\text { eight women }\end{array}$ & $\begin{array}{l}\text { Spot samples (shift urine) } \\
\text { over a } 12 \text { day period after } \\
\text { an interruption of work } \\
\text { for three or four weeks }\end{array}$ & $\begin{array}{l}\text { Within the last three hours of a working shift } \\
\text { during the whole working period and at the } \\
\text { weekend }\end{array}$ \\
\hline 5 & 1987 & $\begin{array}{l}16 \text { men } \\
13 \text { women }\end{array}$ & $\begin{array}{l}\text { Spot samples (shift urine) } \\
\text { over a } 10 \text { day period after } \\
\text { an interruption of work } \\
\text { for three or four weeks; ambient air } \\
\text { concentration measurements }\end{array}$ & $\begin{array}{l}\text { Within the last three hours of a working shift } \\
\text { during the whole working period, and at the } \\
\text { weekend }\end{array}$ \\
\hline 6 & 1987 & $\begin{array}{l}15 \text { men } \\
13 \text { women }\end{array}$ & $\begin{array}{l}\text { Spot sample (urine and blood) } \\
\text { collected at one of five } \\
\text { time points spread over the } \\
\text { year }\end{array}$ & $\begin{array}{l}\text { Within the first two hours of a working shift } \\
\text { (Tuesday, Wednesday, or Thursday) }\end{array}$ \\
\hline 7 & 1988 & $\begin{array}{l}\text { two men } \\
\text { four women }\end{array}$ & $\begin{array}{l}24 \mathrm{~h} \text { urine sample and an } \\
\text { aliquot of shift urine }\end{array}$ & 1200 to 1200 (Monday-Tuesday) \\
\hline 8 & 1989 & $\begin{array}{l}\text { four men } \\
\text { one women }\end{array}$ & $\begin{array}{l}24 \mathrm{~h} \text { urine sample and } \\
\text { aliquots of all single voids }\end{array}$ & 0800 to 0800 (Thursday-Friday) \\
\hline
\end{tabular}

corresponding reaction vessel. The amine formulation was pumped into barrels $(2,4-\mathrm{D}$ amine formulation station). The production process was supervised by measuring instruments and monitors in a control station. Raw materials and products were analysed by special personnel in a chemical laboratory.

\section{METHODS}

Urine and serum analysis

The urine or blood samples were collected in eight separate studies (table 1). Samples of urine were collected in polyethylene vials or bottles and were analysed within two days; otherwise they were stored at $-20^{\circ} \mathrm{C}$ and were analysed not later than two weeks after sampling. Venous blood samples collected in studies 1,2 and 6 were drawn on the mornings within the first three hours of the working shifts. Serum was separated and individual samples were analysed for 2,4-D on the day of sampling. Standard solutions of 2,4-D (Riedel de Haen AG, Seelze/ Hannover, Germany) were prepared in methanol and added to blank urine and blood serum specimens from unexposed persons to cover a range of $1-200 \mathrm{ppb}(\mu \mathrm{g} / \mathrm{l})$. Herbicide residues and standards were analysed by radioimmunoassay as described in detail elsewhere. ${ }^{11}$ Samples of urine and serum were diluted with water to bring them into the optimal measuring range of the radioimmunological method. No other manipulations took place. All samples were assayed in triplicate. The detection limit was $1 \mathrm{ppb}$. Recovery of fortified samples varied from $91 \%-102 \%$.

Creatinine content in urine was determined with an autoanalyser or manually by the Jaffe reaction according to the specifications of the DAB 7 DL pharmacopoeia.

THYROID HORMONES IN BLOOD SERUM

Thyroxin (T4), triiodothyronine (T3), and thyroid stimulating hormone (TSH) content in blood serum samples were measured with the commercially available test kits T3-RIA,
T4-RIA, and TSH-RIA according to the instructions of the manufacturer (Isocommerz/Berlin, Germany).

HUMAN LYMPHOCYTE HISTOCOMPATIBILITY ANTIGENS (HLA CLASS I ANTIGENS)

The typing of HLAs was done with a microlymphocytotoxicity test according to the National Institute of Health (NIH) standard technique. ${ }^{12}$ Lymphocytes were prepared from heparinised blood samples as described elsewhere. ${ }^{13}$ The frequencies of HLAs were compared between the 2,4-D cohort and a group of typed blood donors $(n=1673)$ living in the district of Bitterfeld/Halle, the catchment area of the chemical plant.

\section{AIR SAMPLING AND ANALYSIS}

Concentrations of 2,4-D in air were measured by stationary sampling in the factory as well as personal sampling both on SYNPOR membrane filters (nitrocellulose membranes with a pore size of $2.5 \mu \mathrm{m}$ ). The sampling of the herbicide in the breathing zone of five workers was performed through the use of special tubes and a battery operated device that were worn on the collar of the work clothes. With a sampling air flow of 200-300 $\mathrm{ml} / \mathrm{min}$, volumes of 84-165 litres were collected for six to nine hours-that is, for almost a complete working shift. For stationary air sampling an electric pump (SP 09, Elmet, Hettstedt, Germany) was used. The device, at a height of $150 \mathrm{~cm}$ above the floor, was fixed to a frame and positioned in the different production areas at the most frequented locations during the working process. With an air flow of $300-400 \mathrm{ml} / \mathrm{min}$, volumes of 20-180 litres were collected for one to seven hours of a working shift. Altogether, 12 stationary and eight personally collected samples were analysed. Immediately after sampling membrane filters were put into glass vessels for elution and were covered with $3 \mathrm{ml}$ of methanol. The 2,4-D was measured by two independent methods, gas 
Table 2 Concentrations of 2,4-D in urinary spot samples delivered during the first two hours of a working shift and corresponding values in blood serum samples from studies 1,2 , and 6

\begin{tabular}{|c|c|c|c|c|}
\hline $\begin{array}{l}\text { Worker } \\
\text { No }\end{array}$ & \multicolumn{2}{|c|}{ Sex } & \multicolumn{2}{|c|}{$\begin{array}{l}\text { Concentration of } 2,4-D(p p b) \\
\text { Serum }\end{array}$} \\
\hline 1 & & $\mathbf{M}$ & $362(120)^{\star}$ & $1008(600)$ \\
\hline 2 & $\mathrm{~F}$ & & $852(110)$ & $1868(740)$ \\
\hline 3 & & $\mathbf{M}$ & $126(44)$ & $107(50)$ \\
\hline 4 & F & & 235 & 1287 \\
\hline 5 & $\mathrm{~F}$ & & $196(50)$ & $285(10)$ \\
\hline 6 & $\mathrm{~F}$ & & $1846(75)$ & $3562(530)$ \\
\hline 7 & $\mathrm{~F}$ & & 360 & 1138 \\
\hline 8 & $\mathrm{~F}$ & & $142(140)$ & $399(540)$ \\
\hline 9 & $\mathrm{~F}$ & & 138 & 366 \\
\hline 10 & $\mathrm{~F}$ & & $1305(3790)$ & $3562(19500)$ \\
\hline 11 & & $M$ & $981(42)$ & $1391(950)$ \\
\hline 12 & $\mathrm{~F}$ & & 350 & 1805 \\
\hline 13 & & $\mathbf{M}$ & 282 & 542 \\
\hline 14 & F & & $212(115)$ & $542(700)$ \\
\hline 15 & & M & $364(210)$ & $740(1200)$ \\
\hline 16 & & $\mathbf{M}$ & $1134(320)$ & $3280(1650)$ \\
\hline 17 & & M & $3537(170)$ & $12963(1150)$ \\
\hline 18 & & M & 280 & 314 \\
\hline 19 & & M & 130 & 146 \\
\hline 20 & & $\mathbf{M}$ & 585 & 828 \\
\hline 21 & & M & 195 & 257 \\
\hline 22 & & M & 60 & 35 \\
\hline 23 & & M & 207 & 90 \\
\hline 24 & & $\mathbf{M}$ & 325 & 859 \\
\hline 25 & & M & $262(25)$ & $2881(280)$ \\
\hline 26 & & M & $175(420)$ & $3293(2600)$ \\
\hline 27 & $\mathrm{~F}$ & & $223(180)$ & $1120(1000)$ \\
\hline 28 & & $\mathbf{M}$ & 243 & 2156 \\
\hline 29 & & $\mathbf{M}$ & $186(220)$ & $2538(1300)$ \\
\hline 31 & & $\mathbf{M}$ & $72(85)$ & $577(490)$ \\
\hline 32 & & $\mathbf{M}$ & $26(250)$ & $731(2000)$ \\
\hline 33 & $\mathrm{~F}$ & & 7 & 245 \\
\hline 34 & $\mathrm{~F}$ & & $20(39)$ & $332(820)$ \\
\hline 35 & & $\mathbf{M}$ & $29(330)$ & $359(2900)$ \\
\hline 36 & & M & $43(330)$ & $416(1200)$ \\
\hline 37 & $\mathrm{~F}$ & & $3(41)$ & $198(420)$ \\
\hline 38 & & $\mathbf{M}$ & 55 & 1108 \\
\hline 39 & $\mathrm{~F}$ & & $44(410)$ & $795(1800)$ \\
\hline 40 & & $\mathbf{M}$ & $12(125)$ & $346(400)$ \\
\hline 41 & $\mathrm{~F}$ & & $27(40)$ & $226(56)$ \\
\hline 42 & $\mathrm{~F}$ & & $101(20)$ & $462(410)$ \\
\hline 43 & $\mathrm{~F}$ & & (400) & $(6200)$ \\
\hline 47 & & $\mathbf{M}$ & $(680)$ & $(9500)$ \\
\hline
\end{tabular}

${ }^{\star}$ Numbers in parentheses are from study No 6 .

chromatography and radioimmunoassay. For gas chromatography a $1 \mathrm{ml}$ aliquot of the methanolic eluate was evaporated to dryness under a stream of nitrogen. The residue was redissolved in $2 \mathrm{ml}$ of acetone and sonicated for two minutes. After addition of $100 \mu \mathrm{l}$ of a $5 \%$ pentafluorobenzylbromide solution in acetone the glass vessel was tightly capped and heated to $50^{\circ} \mathrm{C}$ in a water bath for 90 minutes. Then the solution was again evaporated to dryness under nitrogen, taken up in $5 \mathrm{ml}$ of isooctane, and analysed with a Hewlett-Packard 5880 A gas chromatography apparatus equipped with a $50 \mathrm{~m} \times 0.2 \mathrm{~mm}$ internal diameter HP Ultra 2 column and electron capture detector. Gas chromatography conditions were as follows: detector, electron capture ${ }^{63} \mathrm{Ni}$ temperature $300^{\circ} \mathrm{C}$; carrier gas hydrogen; make up gas nitrogen; flow rate through the column $2.3 \mathrm{ml} / \mathrm{min}$; sample volume injected $2 \mu \mathrm{l}$; injector temperature $250^{\circ} \mathrm{C}$; column temperature, programmed at $70^{\circ} \mathrm{C} / \mathrm{min}$ to $250^{\circ} \mathrm{C}$ and maintained for 20 minutes. External standards were used for calibration. Radioimmunoassay was performed as described elsewhere. ${ }^{11}$ Samples were $100 \mu \mathrm{l}$ aliquots of the methanolic eluate or an appropriate dilution with water. Calibration curves were obtained with herbicide standard solutions prepared in these matrices.

\section{Results}

EXPOSURE MEASUREMENTS

Table 2 shows that 2,4-D was detectable in serum and urine of all persons included but in rather different amounts. Mostly 2,4-D concentrations in serum were clearly lower than in urine indicating an active secretion by the kidney. The highest urinary concentration reached almost $19.5 \mathrm{ppm}$ (worker No 10). There were no significant differences in the concentration of 2,4-D between men and women.

From the staff, nine workers with different degrees of exposure in earlier studies were selected for a weekly observation period. By contrast with studies No 1 and 2 spot urine samples in study No 3 were taken during the last three hours of a working shift (fig 1).

The 2,4-D urinary concentration profile for a weekly interval showed an increase in exposure during the week, culminating on Friday. That was confirmed after treating the data $(n=61)$ statistically by ANOVA.
Figure 1 2,4-D urinary concentration profile for a week including the weekend for nine employees (on Friday, no samples were delivered from workers 34 and 35). Fob description: Nos 28 and 31, 2,4-D acid filter station; Nos 26, 29, 33, 35 and 36 , condensation station; Nos 32 and 34, 2,4-D dimethylamine formulation station.

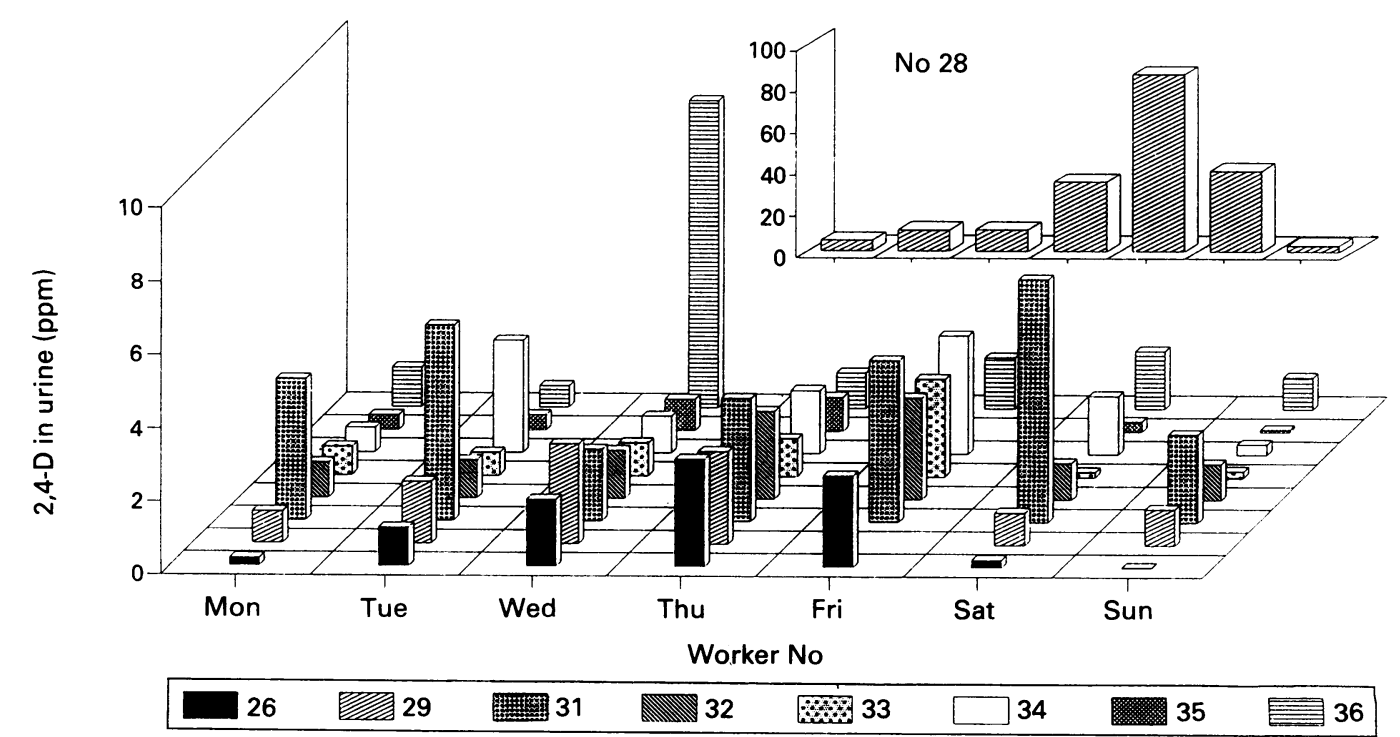


Table 3 Mean daily 2,4-D urinary concentrations after an interruption of work for three or four weeks from studies No $4(n=20)$ and No $5(n=29)$

\begin{tabular}{llllllllllllll}
\hline \multicolumn{1}{c}{ Week 1 } & \multicolumn{1}{c}{ Week 2 } \\
\hline Workday & Mon & Tue & Wed & Thu & Fri & Sat & Sun & Mon & Tue & Wed & Thu & Fri \\
\hline $\begin{array}{l}\text { Mean daily urinary concentration } \\
\text { of 2,4-D (log } \mu \mathrm{g} / \mathrm{l})\end{array}$ & 2.24 & 2.34 & 2.62 & 2.86 & 3.05 & 2.94 & 2.78 & 2.86 & 2.81 & 2.92 & 2.91 & 2.93 \\
$\begin{array}{l}\text { Quotient: week } 2 \\
\text { week 1 }\end{array}$ & 1.34 & 1.20 & 1.11 & 1.02 & 0.96 & & & & & & & \\
\hline
\end{tabular}

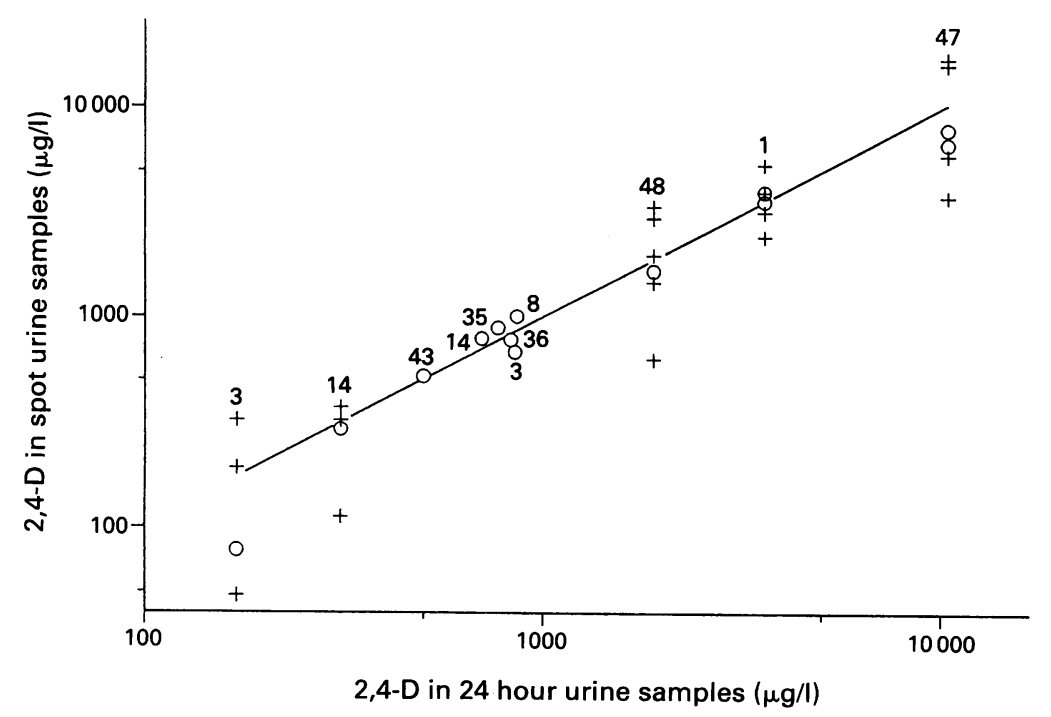

Figure 2 Concentrations of 2,4-D in spot urine samples and corresponding 24 hour urine samples from studies No 7 and $8(+)$. Herbicide concentrations in urinary samples voided within the last three hours of a working shift (shift urine) are marked (0). A regression line $(\log y=0.0088+0.9977 \log x)$ is included $(r s=0.9936)$. The numbers close to the sets of data refer to the worker No.

Table 4 Measurement of stationary 2,4-D air concentration in some main departments Table 4 Measurement of st
of the plant (study no 5)

\begin{tabular}{lccc}
\hline $\begin{array}{l}\text { Production } \\
\text { area }\end{array}$ & $\begin{array}{l}\text { Day of sampling } \\
\text { (day after recom- } \\
\text { mencing work) }\end{array}$ & $\begin{array}{l}\text { Sampling } \\
\text { volume (1) }\end{array}$ & $\begin{array}{l}\text { Estimated TWA } \\
\left(\mu \mathrm{g} / \mathrm{m}^{3} \text { of } 2,4-D\right)\end{array}$ \\
\hline Laboratory & 3 & 26 & $3 \cdot 2$ \\
Control station & 3 & 180 & $9 \cdot 81$ \\
Condensation station & 2 & 75 & $13 \cdot 46$ \\
& 3 & 165 & $12 \cdot 33$ \\
& 4 & 148 & $29 \cdot 12$ \\
& 5 & 162 & $28 \cdot 33$ \\
2,4-D acid filter & 8 & 171 & $20 \cdot 67$ \\
station & 10 & 147 & $35 \cdot 35$ \\
& 3 & 165 & $158 \cdot 55$ \\
& 4 & 170 & $216 \cdot 05$ \\
& 5 & 170 & $192 \cdot 23$ \\
& 9 & 122 & $245 \cdot 66$ \\
\hline
\end{tabular}

Table 5 Measurements of personally monitored 2,4-D air concentration (study No 5)

\begin{tabular}{|c|c|c|c|c|}
\hline $\begin{array}{l}\text { Individual } \\
\text { No }\end{array}$ & $\begin{array}{l}\text { Day of sampling } \\
\text { (day afier recom- } \\
\text { mencing work) }\end{array}$ & $\begin{array}{l}\text { Sampling } \\
\text { volume (1) }\end{array}$ & Work place & $\begin{array}{l}\text { Estimated } T W A \\
\left(\mu g / m^{3} \text { of } 2,4-D\right.\end{array}$ \\
\hline \multirow{4}{*}{$\begin{array}{l}11 \\
17\end{array}$} & 3 & 114 & CS & 31.68 \\
\hline & 3 & 125 & CS & 30.85 \\
\hline & 4 & 174 & CS & 28.28 \\
\hline & 5 & 190 & CS & $23 \cdot 37$ \\
\hline \multirow{3}{*}{$\begin{array}{l}28 \\
29\end{array}$} & 3 & 200 & $\mathbf{A F}$ & $225 \cdot 25$ \\
\hline & 8 & 147 & CS & 27.25 \\
\hline & 9 & 165 & $\mathrm{AF}$ & 495.30 \\
\hline 39 & 8 & 96 & CS & $41 \cdot 87$ \\
\hline
\end{tabular}

$\mathrm{CS}=$ Condensation station; $\mathrm{AF}=2,4-\mathrm{D}$ acid filter station.
Herbicide concentration decreased at the weekend when no work was done but did not return to zero in any case. Irregular concentration profiles were found for some workers (No 29 and 34) with great differences in concentrations of excreted herbicide. With almost $85 \mathrm{ppm}$ No 28 received the highest exposure measured in the five year period of investigation. In the same year, immediately after an interruption of work for three to four weeks and over a 12 day period of investigation, specimens of urine were again taken during the last three hours of a working shift (study No 4). Due to incompleteness of samples (no samples were available on days 1, 2, and 4) and for confirmation of the results, that type of investigation was repeated one year later (study No 5). As was always found in the weekly observation period (study No 3 ), average daily $2,4-\mathrm{D}$ urinary concentration increased over the working week and decreased at the weekend. Obviously, at the end of the first week (after five working days) the steady state of 2,4-D absorption and excretion has almost returned to the initial concentration. Further increases in concentrations of $2,4-\mathrm{D}$ in the urine during the second working week are of less importance (table 3).

From study No 5, stationary as well as personally monitored 2,4-D air concentrations showed large differences between some main departments of the herbicide plant (tables 4 and 5).

The lowest exposures were found in the chemical laboratory and in the control station, with 2,4-D values below $10 \mu \mathrm{g} / \mathrm{m}^{3}$. Some higher concentrations, around 25 $\mu \mathrm{g} / \mathrm{m}^{3}$ on the average, were measured at the condensation station. Air concentrations of 2,4-D were highest in the 2,4-D acid filter working area with average values that reached about $200 \mu \mathrm{g} / \mathrm{m}^{3}$. In the vicinity of the filter, peak concentrations of almost $500 \mu \mathrm{g} / \mathrm{m}^{3}$ were measured.

Eighteen of the air samples were analysed by a gas chromatographic method as well as by radioimmunoassay. Quantitative results of both methods corresponded well with each other establishing, the good reliability of the immunological method $(r=0.9888)$. As well as the 24 hour urine sampling in studies 7 and 8 , shift urine or aliquots of all single urine specimens over the sampling period were measured. Figure 2 shows that individual urinary herbicide concentrations did not vary much within the 24 hours. Concentrations of 2,4-D in shift urines fitted well with the corresponding 24 hour urine samples. Daily renal excretion rates were cal- 
Table 6 Estimated and actual daily 2,4-D urinary exretion from study No 8

\begin{tabular}{|c|c|c|c|c|}
\hline $\begin{array}{l}\text { Individual } \\
\text { No }\end{array}$ & $\begin{array}{l}\text { Spot urine } \\
\text { sampling No }\end{array}$ & $\begin{array}{l}\text { Estimated 2,4-D } \\
\text { excretion (partial } \\
\text { day samples) } \\
\text { ( } \mu \text { g/kg body wt) }\end{array}$ & $\begin{array}{l}\text { Actual } 2,4-D \\
\text { excretion ( } 24 \text { hour } \\
\text { samples) } \\
\text { ( } \mu \text { g/kg body wt) }\end{array}$ & $\begin{array}{l}\text { Estimated excretion/ } \\
\text { actual excretion } \\
(\%)\end{array}$ \\
\hline 1 & $\begin{array}{l}1 \\
2 \\
3 \\
4 \\
5 \\
6 \\
7 \\
8 \\
(24 \mathrm{~h})\end{array}$ & $\begin{array}{c}61 \cdot 48 \\
56 \cdot 64 \\
69 \cdot 14 \\
64 \cdot 0 \\
43 \cdot 98 \\
64 \cdot 64 \\
53 \cdot 34 \\
61 \cdot 96 \\
(57 \cdot 28)\end{array}$ & $67 \cdot 82$ & $\begin{array}{c}90 \cdot 65 \\
83.5 \\
102 \cdot 0 \\
94.4 \\
64.9 \\
95 \cdot 3 \\
78.65 \\
91.36 \\
(84.53)\end{array}$ \\
\hline 3 & $\begin{array}{l}1 \\
2 \\
3 \\
4 \\
5 \\
(24 \mathrm{~h})\end{array}$ & $\begin{array}{c}2 \cdot 33 \\
1 \cdot 25 \\
1 \cdot 73 \\
2 \cdot 23 \\
5 \cdot 04 \\
(2 \cdot 53)\end{array}$ & $2 \cdot 21$ & $\begin{array}{r}105 \cdot 4 \\
56 \cdot 3 \\
78 \cdot 4 \\
105 \cdot 4 \\
228 \cdot 1 \\
(114 \cdot 5)\end{array}$ \\
\hline 14 & $\begin{array}{l}1 \\
2 \\
3 \\
4 \\
(24 \mathrm{~h})\end{array}$ & $\begin{array}{r}2 \cdot 43 \\
3.65 \\
3.97 \\
4 \cdot 14 \\
(4 \cdot 49)\end{array}$ & $2 \cdot 87$ & $\begin{array}{c}84 \cdot 7 \\
127 \cdot 5 \\
138 \cdot 3 \\
144 \cdot 3 \\
(156 \cdot 5)\end{array}$ \\
\hline 47 & $\begin{array}{l}1 \\
2 \\
3 \\
4 \\
5 \\
6 \\
7 \\
(24 \mathrm{~h})\end{array}$ & $\begin{array}{r}114.3 \\
110.4 \\
116.0 \\
123.6 \\
73.9 \\
106.7 \\
132.8 \\
(139.3)\end{array}$ & $137 \cdot 5$ & $\begin{array}{c}83 \cdot 1 \\
80 \cdot 3 \\
84 \cdot 4 \\
89 \cdot 9 \\
53 \cdot 8 \\
77 \cdot 6 \\
96 \cdot 6 \\
(101 \cdot 3)\end{array}$ \\
\hline 48 & $\begin{array}{l}1 \\
2 \\
3 \\
4 \\
5 \\
6 \\
7 \\
(24 \mathrm{~h})\end{array}$ & $\begin{array}{l}54 \cdot 7 \\
38 \cdot 4 \\
58 \cdot 8 \\
49 \cdot 1 \\
39 \cdot 64 \\
23 \cdot 9 \\
42 \cdot 1 \\
(57 \cdot 78)\end{array}$ & 65.94 & $\begin{array}{c}83 \cdot 0 \\
58 \cdot 2 \\
89 \cdot 2 \\
74 \cdot 5 \\
60 \cdot 1 \\
36 \cdot 3 \\
63 \cdot 9 \\
(87 \cdot 7)\end{array}$ \\
\hline
\end{tabular}

Figure 3 Estimated daily urinary excretion rates of herbicide ( $\mu \mathrm{g} / \mathrm{kg}$ body $w t)$ of the staff as based on the available 2,4-D and creatinine measurements of the five year investigation period. culated based on herbicide concentrations in 24 hour urine samples. The lowest 2,4-D exposure of $161 \mu \mathrm{g} /$ day or $2 \cdot 21 \mu \mathrm{g} / \mathrm{kg}$ body wt/day was found for subject No 3 and the highest for No 47 with $10450 \mu \mathrm{g} /$ day or $137.5 \mu \mathrm{g} / \mathrm{kg}$ of body wt/day.

From studies 2,4 , and 5 , we found a high correlation between 2,4-D elimination in urine and excretion of endogeneous creatinine. On the assumption that $2,4-\mathrm{D}$ is excreted by a similar mechanism to creatinine

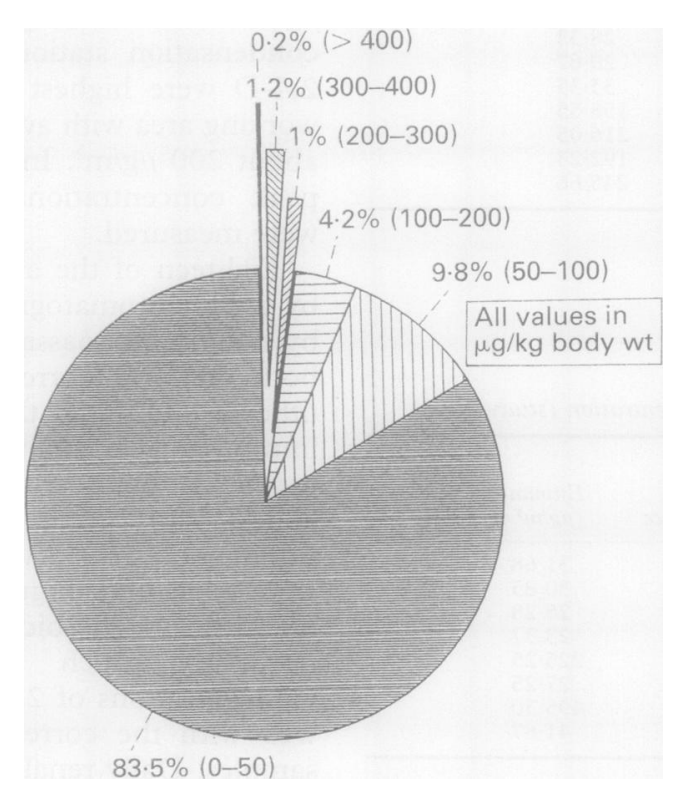

and therefore that the partial day urine samples contain about the same fraction of the total 24 hour excretion for both compounds, study No 8 was carried out for confirmation. In that study, estimation of the daily 2,4-D urinary excretion by adjusting the $2,4-\mathrm{D}$ concentration for endogeneous creatinine in partial day urine samples was investigated. Mean urinary creatinine excretions of $0.2 \mathrm{mmol}$ for men and $0.155 \mathrm{mmol}$ for women $/ \mathrm{kg}$ body wt have been assumed. ${ }^{14}$ Table 6 confirmed the validity of this assumption. Estimated values accord well with the corresponding actual excretion rates derived from 24 hour samples (mean (SD) $92.9 \%(34.2 \%)$, range $(36.3 \%$ $228 \cdot 1 \%), n=36$ ).

Based on estimated daily excretion rates, the distribution of urinary herbicide elimination among the staff (fig 3 ) included all the available values of the five year investigation period. About $83 \%$ of the excretion rates were below $50 \mu \mathrm{g} / \mathrm{kg}$ body wt. Only $6 \cdot 7 \%$ amounted to more than $100 \mu \mathrm{g} 2,4-\mathrm{D} / \mathrm{kg}$ body wt, the value assumed by the World Health Organisation (WHO) to be absorbed, on the average, by people who work with 2,4-D. ${ }^{15}$

\section{SELECTED PARACLINICAL PARAMETERS}

In 1987, thyroid hormone content in blood was measured during routine biennial health monitoring of the staff. Thyroxin concentrations of all workers were normal. Patients 2, 8,29 , and 31 had values between $3 \cdot 1$ and $4 \cdot 1$ $\mathrm{nmol} / \mathrm{l}$. Minor deviations from the normal range of triiodothyronine $(1-3 \mathrm{nmol} / \mathrm{l})$ were found. Patient no 31 had a low TSH content of $0.56 \mathrm{mU} / 1$ (normal lower limit $0.8 \mathrm{mU} / \mathrm{l}$ ). The importance of differential genetic susceptibility in the aetiology and pathogenesis of diseases is now appreciated. Studies of specific genetic markers (such as HLAs and polymorphic enzyme systems) may be of help in detecting genetic susceptibility to the effects of environmental factors. ${ }^{16}$

In the present investigation, because of a prospective follow up study about the association of specific types of cancer and occupational exposure to 2,4-D the workers and controls were typed for HLAs (ABC antigens). The phenotypic frequencies in the 2,4-D exposed group were compared with those of a group of blood donors living in the catchment area of the chemical plant.

Despite the fact that the number of workers included in the exposed group was very small compared with the controls ( $n=27 v$ $n=1673$ ), phenotypic frequencies of HLA$\mathrm{ABC}$ antigens had similar distributions.

\section{Discussion}

Vural and Burgaz reported urinary concentrations of 2,4-D amounting to $0.06-9.51 \mathrm{ppm}$ in 15 persons who were employed full time (six hours daily) in the manufacture of isooctyl esterification of 2,4-D acid and in the formulation of isobutyl ester, isooctyl ester of $2,4-\mathrm{D}$, and dimethylamine salt of 2,4-D.9 These concentrations are similar to the 
Table 7 Urinary exretion rates of 2,4-D as measured in 24 hour urine or calculated from the TWA in study No 8

\begin{tabular}{|c|c|c|c|c|c|}
\hline Individual No & 48 & 3 & 14 & 1 & 47 \\
\hline Production area & $\mathrm{AF}$ & CRS & Lab & $\mathrm{CS}$ & CS \\
\hline $\begin{array}{l}2,4-\mathrm{D} \text { urinary excretion rate as } \\
\text { measured in } 24 \text { hour urine } \\
(\mu \mathrm{g} / \mathrm{kg} \text { body wt) }\end{array}$ & 65.9 & $2 \cdot 2$ & $2 \cdot 8$ & $67 \cdot 8$ & $137 \cdot 5$ \\
\hline $\begin{array}{l}2,4-\mathrm{D} \text { urinary excretion rate as } \\
\text { calculated from TWA } \\
(\mu \mathrm{g} / \mathrm{kg} \text { body } \mathrm{wt})\end{array}$ & $70 \cdot 0$ & $2 \cdot 0$ & $2 \cdot 0$ & $5 \cdot 0$ & $5 \cdot 0$ \\
\hline
\end{tabular}

$\mathrm{AF}=$ Acid filter station; $\mathrm{CRS}=$ control station; Lab = laboratory; $\mathrm{CS}=$ condensation station

$0.035-12.96 \mathrm{ppm}$ found in 43 spot urine samples collected in the first two studies. Corresponding herbicide concentrations in blood were somewhat lower with amounts of $0.003-3.54 \mathrm{ppm}$ indicating an active renal excretion as described for $2,4-\mathrm{D}$ in rats. ${ }^{1718}$ When given phenoxyacid herbicides and probenecid simultaneously, however, renal excretion was inhibited. ${ }^{19}$ Great differences in the urinary concentrations between the workers gave rise to speculation that local conditions of exposure varied. After an observation period of one week, this was confirmed. Also, irregular 2,4-D urinary concentration profiles of some employees (Nos 29 and 34) pointed to temporal fluctuations in exposure.

In 1984, it was stated by WHO that in the case of occupationally exposed workers further consideration should be given to the chemobiokinetics of 2,4-D under repeated exposure conditions. ${ }^{15}$ No data from industry relating to that topic were available. Based on exposure data for 2,4,5-trichlorophenoxy acetic acid in forestry Libich et al developed a model to relate the urinary concentrations of herbicide to equivalent daily exposure. ${ }^{20}$ According to that model, after four to five days the elimination rate equals the dose rate if successive equal doses are applied. There are many limitations to this model especially when applied to conditions prevailing in industry. The dose rates, for instance, are not equal on a daily basis but vary with job category. Furthermore, the biological half lives and the time of urine sampling are factors contributing to uncertainties in relating 2,4-D urinary concentrations to exposures. Nevertheless, table 3 shows that in this investigation with a longer period free of exposure total body concentration built up again after about five working days. Further increase in urinary concentration during the second week was negligible. Accompanying measurements of 2,4-D air concentration showed different air loads in relation to the workplace. Estimated time weighted average (TWA) values $\left(\mathrm{mg} / \mathrm{m}^{3}\right)$ ranged from about 0.01 (laboratory, control station) to almost 0.5 (acid filter station). This is in accordance with data from Bond et al who found that differences in 2,4-D air concentrations depend on production area (job category). Exposure conditions in an early organic semiplant were worse than in a modern herbicides plant. ${ }^{21}$ Based on a standard man ( $70 \mathrm{~kg}$ body wt) inhaling $10 \mathrm{~m}^{3}$ of air in an eight hour working day, herbicide excretion rates for persons working in the different production areas could be estimated from the TWA. These rates hardly exceeded 2.0 at the laboratory and the control station, 5.0 at the condensation station, and about $70 \mu \mathrm{g} / \mathrm{kg}$ body wt/day at the $2,4-\mathrm{D}$ acid filter station. As will be discussed later, daily excretion rates of urinary $2,4-\mathrm{D}$ derived from spot samples or measured in 24 hour urine samples are in some cases higher than the estimated excretion rates calculated from a typical TWA. This points to routes of entry other than inhalation (table 7).

This statement has to be qualified by the fact that workers during a working day normally enter different production areas so that a clear cut allocation to one single TWA for the whole time of a working shift is nearly impossible. Nevertheless, dermal resorption could play an important part, especially for persons who are in direct contact with the herbicide through their hands and uncovered skin (2,4-D acid filter). As found by Moody et al uncovered skin on the human forehead is very permeable to phenoxyacid herbicides. ${ }^{22}$ More studies should be done to better evaluate the different routes of exposure under conditions found in the chemical industry.

To obtain the most precise individual exposure data complete urine sampling should be done. In practice, this is often difficult. As an alternative, metabolite concentrations in spot urine samples in some cases were corrected for creatinine or specific weight of urine to get an estimation of daily excretion rates. As our investigations showed, there was a strong correlation between concentration of urinary 2,4-D and the amount of excreted herbicide adjusted for endogeneous creatinine. Although creatinine clearance is extensively used in clinical studies as a measure of glomerular filtration rate it is well recognised that about $10 \%$ to $40 \%$ of the clearance of creatinine in humans is due to active tubular secretion. ${ }^{23}$ Because of its high plasma protein binding renal excretion of $2,4-\mathrm{D}$ by glomerular filtration is almost negligible. The main processes are active tubular secretion and reabsorption of the herbicide. Obviously, the different mechanisms of excretion lead to an approximation of creatinine and 2,4-D clearances.

There was good agreement between daily herbicide excretion rates measured in 24 hour samples with extrapolated values derived from adjusted concentrations in partial day urine specimens $(92.9 \%(34.2 \%))$. This finding emphasises the association of elimination of creatinine and 2,4-D. Possible influences of urinary $\mathrm{pH}$ and diurnal excretion profile should be investigated in more detail, however, in further studies.

Based on all the available data for the five year study the distribution of estimated daily excretion rates (fig 3) showed that most values were lower than $50 \mu \mathrm{g} / \mathrm{kg}$ body wt and therefore indicated a fairly low exposure. A further $10 \%$ could be attributed to the range of $50-100 \mu \mathrm{g} / \mathrm{kg}$ body wt, and only about $6 \%$ of the values amounted to $100-400 \mu \mathrm{g} / \mathrm{kg}$ 
body wt. One single, extremely high excretion rate of $738.5 \mu \mathrm{g} / \mathrm{kg}$ body wt was found.

The estimated doses were several orders of magnitude below the no observed adverse effect level of $36 \mathrm{mg} / \mathrm{kg}$ body wt/day for acute toxic effects and below the no observed adverse effect level of $10 \mathrm{mg} / \mathrm{kg}$ body wt/day for embryotoxic, fetotoxic, and teratogenic effects of 2,4-D. ${ }^{19}$ Therefore, the resulting safety factors for more than $90 \%$ of the estimated daily excretion rates are greater than 360 and 100 respectively and the received exposure should not constitute a serious health hazard. Only $6.6 \%$ of the estimated values resulted in safety factors lower than 50 for embryotoxic, fetotoxic, and teratogenic effects pointing to a possible health hazard from exposure to 2,4-D. ${ }^{15}$ Moreover, the carcinogenic potential of this herbicide is still under evaluation by the international scientific community and findings are controversial. ${ }^{24-34}$ The association between apparent exposure to 2,4-D and soft tissue sarcoma and malignant lymphoma, if any, could be the result of contaminating dioxins. ${ }^{35} 36$ In a case-control study including 237 cases with soft tissue sarcoma and 237 controls, Eriksson et al found a non-significantly increased risk (rate ratio of 1.34) for soft tissue sarcoma after exposure to phenoxyacetic acid of all types. Exposure to 2,4,5trichlorophenoxyacetic acid $(2,4,5-\mathrm{T})$ or high grade exposure to chlorophenols gave a roughly three or fivefold significantly increased risk, respectively. We attributed the increased risk to polychlorinated dioxin (PCDD) contamination, which is well known to occur especially in commercial products of $2,4,5-T$ and some chlorophenols. The investigation indicated that not only the tetrachlorodibenzodioxin 2,3,7,8-TCDD but also other higher chlorinated isomers might be risk factors for soft tissue sarcoma.

Earlier chemical analysis by gas chromatography-mass spectrometry of the technical 2,4-D produced in the chemical plant under investigation in the present study showed mainly polychlorinated diphenylether as a byproduct. Furthermore, tetrachlorodibenzodioxins (1,3,6,8-TCDD; 1,3,7,9-TCDD) were found at concentrations of $10 \mathrm{ppb}$ as well as tetra and pentachlorodibenzofurans at relatively high concentrations of $400 \mathrm{ppb}$ (personal communication). At present, little is known about the toxicology of polychlorinated dioxins and pentachlorodibenzofurans, especially on long term effects. ${ }^{37}$ Risk assessment and management of these compounds are just being conducted in various countries. ${ }^{38}$ Therefore, the health risk for the highest exposed workers in the present study might be unacceptably high. Uncertainties call for a technology in 2,4-D production that ensures that chemical exposure of employees is as low as possible.

The immunochemical determination of 2,4-D in the urine specimens of exposed workers in chemical plants is a simple, cost effective, and non-invasive method. Therefore, analysis of urine samples may replace or complement the more time consuming and expensive air monitoring. Furthermore, it permits assessment of the actual body exposure. Workers at increased risk could then be picked out. Samples should be taken over several days at the end of the workshift or in the morning. As well as urinary 2,4-D, creatinine should be analysed and could be used to estimate daily rates of herbicide excretion.

Besides inhalation, dermal exposure seems to be an important route of entry into the body. Especially in those production areas where a direct contact between herbicide and the skin is very likely, excessive exposure to 2,4-D can be avoided by fairly simple measures of occupational hygiene, including responsible behaviour of the worker towards hygiene. The exposure to herbicide during the production process should amount to well

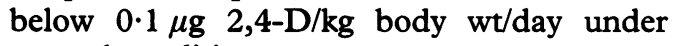
normal conditions.

The immunochemical method used in these studies proved to be a practicable tool for biological monitoring in occupational health. The development of immunoassays for other compounds like polycyclic aromatic hydrocarbons is in progress at our laboratory.

I sincerely thank S Renz, M Skerswetat, and I Weidhaas for skillful technical assistance. I also gratefully acknowledge the support of Dr G Richter from the Health Department of the Chemie AG Bitterfeld/Wolfen in the preparation of biological samples, D Knape and $G$ Illmer from the Chemie AG Bitterfeld/Wolfen for 2,4-D air sampling, Dr H Hermenau and Dr E Stottmeister from the Institute for Water, Soil, and Air Hygiene of the Federal Health Office, Research Department, Bad Elster for the 2,4-D analysis by gas liquid chromatography, U Born from the Transfusion Institute Plauen for HLA typing, Dr A Tetzlaff from the Transfusion Institute Halle for data about the HLA frequencies of blood donors living in that area, and $W$ Deschner from the Institute for Clinical Chemistry at the Central Hospital Plauen for the determination of thyroid hormones. I thank Professor $\mathrm{H}$ determination of thyroid hormones. I thank Professor the
Lange-Asschenfeldt and Professor M Wagner from the
Institute for Water, Soil, and Air Hygiene of the Federal Institute for Water, Soil, and Air Hygiene of the

Health Office for critically reviewing the manuscript.
The investigations were performed at the Institute for The investigations were performed at the Institute for
Water, Soil, and Air Hygiene of the Federal Health Office, Research Department, Bad Elster. Results were presented in part at the 3rd inhalation symposium: advances in controlled clinical inhalation studies, 9-11 October 1991, Hannover, Germany.

1 Frank R, Campbell RA, Sirons GJ. Forestry workers involved in aerial application of 2,4-dichlorophenoxyacetic acid (2,4-D): exposure and urinary excretion. Arch Environ Contam Toxicol 1985;14:427-35.

2 Grover R, Cessna AJ, Muir NI, Riedel D, Franklin CA, Yoshida K. Factors affecting the exposure of ground-rig applicators to 2,4-D dimethylamine salt. Arch Environ Contam Toxicol 1986;15:667-86.

3 Grover R, Franklin CA, Muir NI, Cessna AJ, Riedel D. Dermal exposure and urinary metabolite excretion in farmers repeatedly exposed to $2,4-\mathrm{D}$ amine. Toxicol Lett farmers repeatedly

4 Harris SA, Solomon KR. Human exposure to 2,4-D following controlled activities on recently sprayed turf f Environ Sci Health[B] 1992;27:9-22.

5 Harris SA, Solomon KR, Stephenson GR. Exposure of homeowners and bystanders to 2,4-dichlorophenoxyacetic acid. F Environ Sci Health[B] 1992;27:23-8.

6 Kolmodin-Hedman B, Höglund S, Akerblom M. Studies on phenoxy acid herbicides. I. Field study: occupational exposure to phenoxy acid herbicides (MCPA, Dichlorprop, Mecoprop and 2,4-D) in agriculture. Arch Toxicol 1983;54:257-65.

7 Lavy TL, Walstad JD, Flynn RR, Mattice JD. (2,4Dichlorophenoxy)acetic acid exposure received by aerial application crews during forest spray operations. $\mathcal{F}$ Agri Food Chem 1982;30:375-81.

8 Taskar PK, Das YT, Trout JR, Chattopadhyay SK Brown HD. Measurement of 2,4-dichlorophenoxyacetic acid $(2,4-D)$ after occupational exposure. Bull Environ acid (2,4-D) atter occupational

9 Vural N, Burgaz S. A gas chromatographic method for determination of 2,4-D residues in urine after occupational exposure. Bull Environ Contam Toxicol 1984;33. 518-24. 
10 Knopp D, Glass S. Biological monitoring of 2,4dichlorophenoxyacetic acid-exposed workers in agriculture and forestry. Int Arch Occup Environ Health 1991; ture and for

11 Knopp D, Nuhn P, Dobberkau HJ. Radioimmunoassay for 2,4-dichlorophenoxyacetic acid. Arch Toxicol 1985;58:27-32.

12 Brand BD, Ray IL, Hare DB, Kayhoe DE, McClelland JD. Preliminary trials toward standardization of leukocyte typing. In: Histocompatibility testing. Copenhagen: Munksgaard, 1970:357-67.

13 Menzel GR, Richter KV. Eine Methode zur Isolierung von Lymphozyten für die Gewebetypisierung. $Z \mathrm{Med}$ Lab Diagn 1971;12:211-2.

14 Rapoport SM, Raderecht HJ. Physiologisch-chemisches Praktikum. Berlin: VEB Verlag Volk und Gesundheit, 1977; 385.

15 World Health Organization. 2,4-Dichlorophenoxyacetic acid. Geneva: WHO, 1984. (Environmental health criteria No, 29.)

16 Khoury MJ, Stewart W, Beaty TH. The effect of genetic susceptibility on causal inference in epidemiologic studies. Am F Epidemiol 1987;126:561-7.

17 Koschier FJ, Girard PR, Hong SK. Transport of 2,4dichlorophenoxacetate by rat renal cortical slices. Toxicol Appl Pharmacol 1978;45:883-94.

18 Koschier FJ, Pritchard JB. Renal handling of 2,4-D by the dogfish shark. Xenobiotica 1980;10:1-6.

19 Bräunlich H, Bernhardt H, Bernhard I. Renal handling of 2-methyl-4-chlorophenoxyacetic acid (MCPA) in rats. f Appl Toxicol 1989;9:255-8.

20 Libich S, To JC, Frank R, Sirons GJ. Occupational exposure of herbicide applicators to herbicides used along sure of herbicide applicators to herbicides used along
electric power transmission line right-of-way. Am Ind Hyg Assoc f 1984;45:56-62.

21 Bond GG, Wetterstroem NH, Roush GJ, McLaren E, Lipps TE, Cook RR. Cause specific mortality among employees engaged in the manufacture, formulation, or packaging of 2,4-dichlorophenoxyacetic acid and related salts. Br F Ind Med 1988;45:98-105.

22 Moody RP, Franklin CA, Ritter L, Maibach HI. Dermal absorption of the phenoxy herbicides 2,4-D, 2,4-D amine, 2,4-D isooctyl, and 2,4,5-T in rabbits, rats, rhesus monkeys, and humans: a cross-species comparison. $\mathcal{F}$ Toxicol Environ Health 1990;29:237-45.

23 Darling IM, Morris ME. Evaluation of "true" creatinine clearance in rats reveals extensive renal secretion. Pharm Res $1991 ; 8: 1318-22$.

24 Cole Johnson C, Feingold M, Tilley B. A meta-analysis of exposure to phenoxy acid herbicides and chlorophenols in relation to risk of soft tissue sarcoma. Int Arch Occup Environ Health 1990;62:513-20.

25 Hardell L, Eriksson M. The association between soft tissue sarcomas and exposure to phenoxyacetic acids. Cancer 1988;62:652-6.

26 Hayes HM, Tarone RE, Cantor KP, Jessen $C K$ McCurnin DM, Richard RC. Case-control study of canine malignant lymphoma: positive association with dog owner's useof 2,4-dichlorophenoxyacetic acid herbicides. F Natl Cancer Inst 1991;83:1226-31.

27 Ibrahim MA, Bond GG, Burke TA, et al. Weight of the evidence on the human carcinogenicity of 2,4-D. Environ Health Perspect 1991;96:213-22.

28 Johnson ES. Association between soft tissue sacromas, malignant lymphomas, and phenoxy herbicides/ chlorophenols: evidence from occupational cohort studchlorophenols: evidence from occupation

29 Lilienfeld DE, Gallo MA. 2,4-D, 2,4,5-T, and 2,3,7,8TCDD: An overview. Epidemiol Rev 1989;11:28-58.

30 Mullison WR, Bond GG. Epidemiology and Toxicology Mullison WR, Bond GG. Epidemiology and
of 2,4-D. Weed Technology 1991;5:896-906.

31 Persson B, Dahlander AM, Fredriksson $M$, Noorlind Brage $\mathrm{H}$, Ohlson CG, Axelson O. Malignant lymphomas and occupational exposures. $\mathrm{Br} \mathcal{F}$ Ind $\mathrm{Med}$ 1989;46:516-20.

32 Smith JG, Christophers AJ. Phenoxy herbicides and chlorophenols: a case control study on soft tissue sarcoma and malionant lymphoma $\mathrm{Br} \mathcal{F}$ Cancer 1992;65:442-8.

33 Vineis $\mathbf{P}$, Settimi L, Costantini AS. Esposizione a fitofarmaci e rischio oncogeno. Med Lav 1990;81:363-72.

34 Wingren G, Fredriksson M, Noorlind Brage $\mathbf{H}$ Nordenskjöld B, Axelson O. Soft tissue sarcoma and occupational exposures. Cancer 1990;66:806-11.

35 Eriksson M, Hardell L, Adami HO. Exposure to dioxins as a risk factor for soft tissue sarcoma: a populationbased case-control study. F Natl Cancer Inst 1990; 82:486-90.

36 Manz A, Berger J, Dwyer JH, Flesch-Janys D, Nagel S, Waltsgott $\mathrm{H}$. Cancer mortality among workers in chemical plant contaminated with dioxin. Lancet 1991; 338:959-64.

37 Skene SA, Durhurst IC, Greenberg M. Polychlorinated dibenzo-p-dioxins and polychlorinated dibenzofurans: the risk to human health. A review. Hum Toxicol 1989;8:173-203.

38 Muto $H$, Takizawa $Y$. Potential health risk via inhalation/ingestion exposure to polychlorinated dibenzo-p-dioxins and dibenzofurans. Bull Environ Contam Toxicol 1992;49:701-7.

\section{Correspondence and editorials}

Occupational and Environmental Medicine welcomes correspondence relating to any of the material appearing in the journal. Results from preliminary or small scale studies may also be published in the correspondence column if this seems appropriate. Letters should be not more than 500 words in length and contain a minimum of references. Tables and figures should be kept to an absolute minimum. Letters are accepted on the understanding that they may be subject to editorial revision and shortening.

The journal also publishes editorials which are normally specially commissioned. The Editor welcomes suggestions regarding suitable topics; those wishing to submit an editorial, however, should do so only after discussion with the Editor. 